\title{
COMMD1 wt Allele
}

National Cancer Institute

\section{Source}

National Cancer Institute. COMMD1 wt Allele. NCI Thesaurus. Code C90489.

Human COMMD1 wild-type allele is located in the vicinity of 2p15 and is approximately $388 \mathrm{~kb}$ in length. This allele, which encodes COMM domain-containing protein 1, plays a role in the modulation of NF-kappa-B signaling, copper homeostasis and sodium uptake. The gene is aberrantly expressed in many tumors. 